\title{
ON THE CHANGE OF HISTORIC HOSPITAL SPACES AND FURNISHING DESIGNS FROM 13TH TO 17TH CENTURY IN ANATOLIA
}

\author{
GÜLŞEN DİŞLI' ${ }^{1}$ \\ Necmettin Erbakan University, Faculty of Engineering and Architecture, \\ Department of Architecture, Turkey
}

\begin{abstract}
As the core places of healthcare systems and medicine education, understanding of working principles, conceptual designs and specific characteristics of the functional spaces in historic hospitals of Anatolia can potentially contribute significantly to survival of those buildings. Attention to the change of historic hospital spaces and the original furnishing designs in those spaces is, however, rather a rare research area. Hence, this article argues that a proper determination of functional spaces and their original furnishing designs is an essential step requiring a comprehensive research. Therefore, this article first aimed at analysing different functions of the spaces in total 12 case study hospitals reflecting their unique culture and history and developmental stage of their own period as well. The functional spaces include patients' rooms, pharmacy, policlinics, latrines, surgery rooms, baths, kitchens and many others. The focus of this study is on the historic hospitals still existent today in Anatolia built from the 13th to 17 th centuries, constructed by Seljuks and Ottomans. Literature, archival and historical survey as well as in situ observations are the main methods applied during this study. Among them, waqf deeds, gravures, miniatures, accounting registers, excavation reports and travellers' accounts were the basic primary sources. The case study hospitals from Seljuk and Ottoman periods have been compared in terms of similarities and differences of their functional spaces and furnishing design arrangements. The research showed that as a result of the increasing needs and developments in technology, different spaces were designed nearly for all functions, and many others were lost during the transition period from Seljuks to Ottomans.

Keywords: Anatolia, Seljuk and Ottoman periods, functional spaces, furnishing, historic hospitals, interior fittings.
\end{abstract}

\section{INTRODUCTION}

During the Seljuk and the Ottoman periods, hospitals of Anatolia were mostly built to serve for the poor and homeless patients in need, for the insane, for the ones with contagious diseases, and for the merchants, travellers, explorers and strangers of the city, free of charge [1-3]. However, in those times, it was common to care for the patients at their own homes by their own families, and to call for the physicians only if they had a serious disease (Fig. 1) $[1,2]$. In Anatolian Seljuk and Turkish Principalities periods, physicians did not only serve the hospitals. There were also physicians working in the palace, working in their own clinics, working for the army treating the wounded soldiers at the battlefields and making and selling medications, and there were self-employed and easily available surgeons and orthopaedists (Fig. 1) [2, 4]. A good understanding of functional spaces and original furnishing designs of historic hospitals is required in order to address issues of their proper preservation and possibly transfer of the past knowledge to modern hospital designs. Hence, this article examines four hospitals from Seljuk period, and eight from Ottoman period remain today in Anatolia, in order to enhance our understanding of the variety of design solutions of functional spaces with their furnishings and their gradual development over time.

1 ORCID: https://orcid.org/0000-0003-2620-0492 

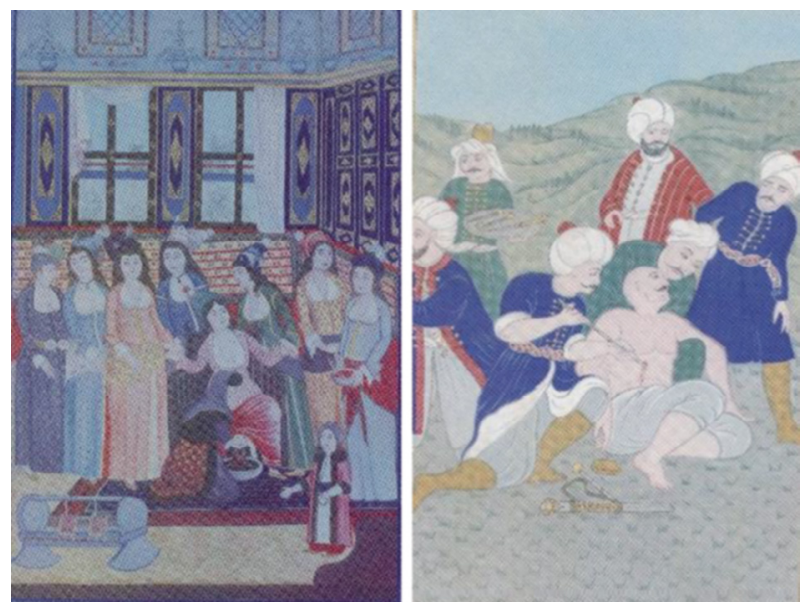

Figure 1: A miniature depicting a birth scene in a mansion (left) (Enderunî Hüseyin Fazıl: Zenân-nâme, Istanbul University Book Number 5502, vr. 142a, painted by Ülker Erke), and a drawing of a battlefield showing 16th-century Ottoman military surgeons treating the wounded patient (right) (Della Officina chirurgica d'Andrea Della Croce, Venezia, 1596, painted by Ulker Erke) [5].

\section{ON THE DEVELOPMENT OF FUNCTIONAL SPACES IN THE ANATOLIAN SELJUK AND THE OTTOMAN HOSPITALS: A COMPARATIVE ANALYSIS}

Historic hospitals were important places for healthcare quality. They were built not only for the treatment of patients but also for medical education, policlinic and medicine preparation duties [2]. Though historic hospitals of Anatolia received remarkable attention from researchers in terms of their architecture, decoration and pharmaceutical and education activities held, data on the functional space analysis for these buildings is rather limited [4, 6, 7]. Hence, by using primary and secondary sources, this article presents the 4th-century long development of hospital spaces in Anatolia. Historic court registers, travellers' accounts, old drawings, photographs, gravures, waqf deeds as well as research excavations and in situ observations have been the primary sources used during this study [1]. In Anatolian Seljuk period, hospitals were constructed especially in big cities along the trade routes. But Ottomans either used the ones built in Seljuk period or constructed hospitals as part of a mosque complex in big cities such as Bursa, Edirne and Istanbul, which were once the capital of Ottoman Empire in different periods, and did not build any in cities if there already existed a hospital from Seljuk period $[1,2,8,9]$.

By using primary and secondary sources, from the few Seljuk and Ottoman period hospitals in Anatolia that still remain to us, the main functional spaces in a hospital appear to be patients' rooms, policlinic, office rooms, rooms for medicine students, classrooms, surgery rooms, pharmacy, pharmaceutical store, drug preparation room, bakery, kitchen, bath and latrine [1]. These spaces have been classified under specific headings as 'treatment spaces', 'spaces related to pharmacy', 'education spaces', 'service spaces', 'administrative spaces', and 'other functional spaces' (Figs 2-4) [8, 9]. Policlinics, surgery rooms and patients' rooms have been classified as 'treatment spaces', pharmacy, pharmaceutical stores and drug 


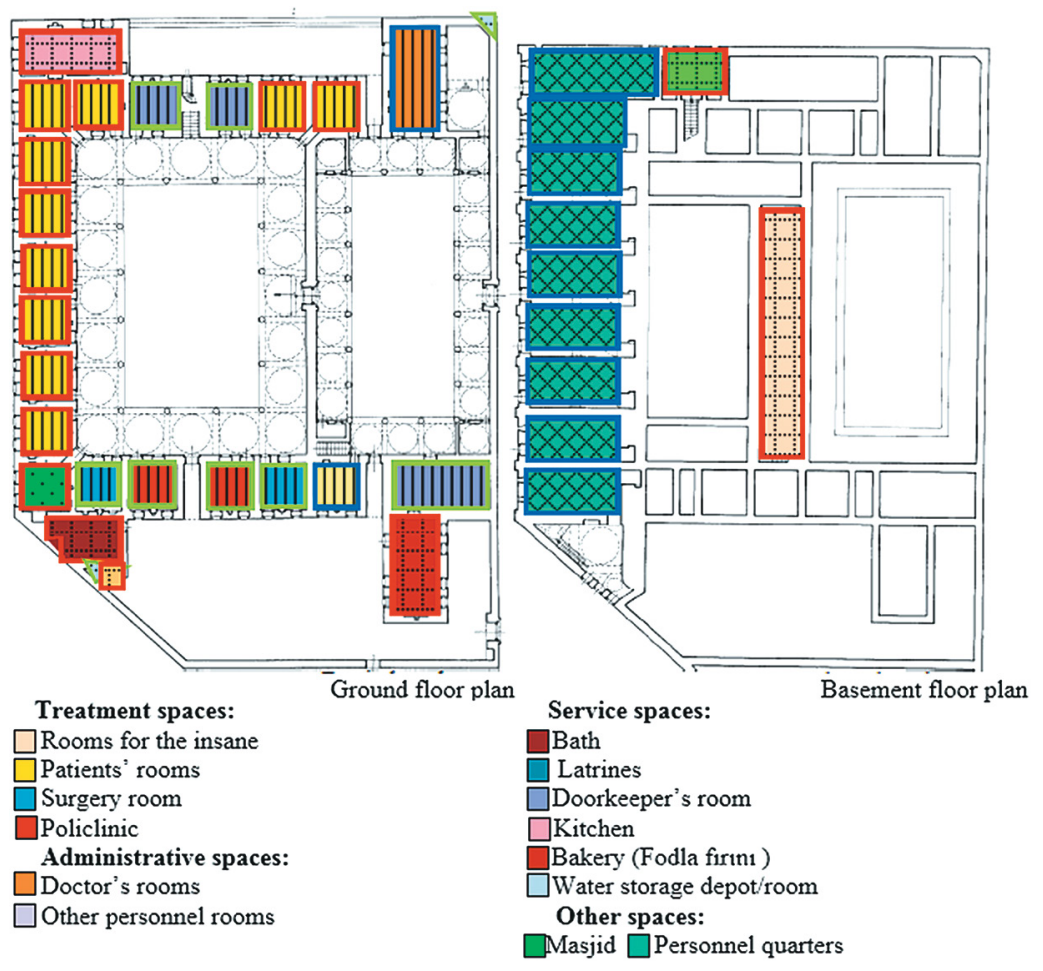

Figure 2: A plan drawing of Istanbul, Süleymaniye Hospital, with analysis of functional spaces shown in different colours [9].

preparation rooms as 'spaces related to pharmacy', classrooms, rooms for medicine students and teachers' rooms as 'education spaces', bakery, kitchen, bath, toilet, courtyard and cellar as 'service spaces', doctors' rooms and office rooms as 'administrative spaces' and finally tomb, masjid, stables, stores and personnel lodges as 'other functional spaces'. Similarly, possible functions of spaces in the medicine madrasahs have been determined as students' rooms, teachers' rooms, iwan/summer classroom, winter classroom, tomb, masjid and latrine $[1,8,9]$ (Table 1).

In waqf deeds belonging to the hospitals, the official staff and their duties were explained in detail, and thus it becomes possible to determine various related spaces and the staff working there $[1,8,9]$. Similarly, examining functional systems/ancient installation infrastructure such as heating, refrigeration, ventilation, illumination, waste and clean water and drainage systems in historic hospitals, and combining this data with waqf deeds, other archival sources, and research excavations, it became possible to fix the location of certain functional spaces [1, 8-15]. For instance, during the functional system investigations and research excavations held in case study buildings, terracotta pipelines, waste water collection and discharge channels, water depots, hypocaust sections, fireplaces, roof lanterns and openings were unearthed and revealed, and thus it became possible to locate the bath, pharmacy, latrines, kitchen, cellar, laundry and patients' rooms in these hospitals [1,8-15]. As an instance, thanks to the excavations and in situ observations, the bath section of Sivas I. Izzeddin Keykavus Hospital, 


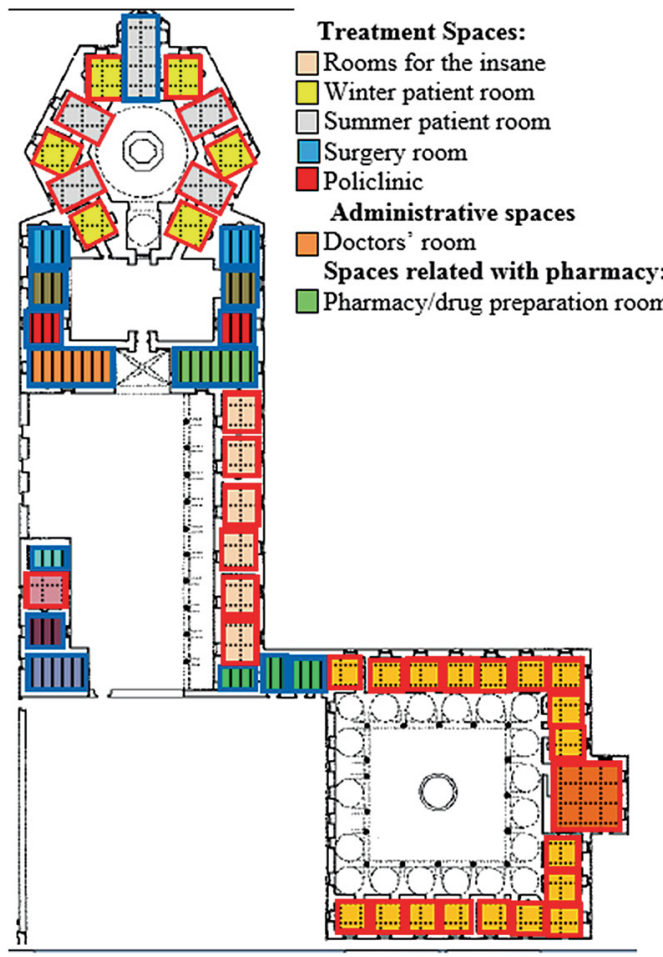

Spaces related with education:

$\square$ Students' rooms

Winter classroom/classroom

Service spaces:

$\square$ Patients' waiting room

$\square$ Doorkeeper's room

$\square$ Toilet

$\square$ Cellar

$\square$ Kitchen

Laundry

Figure 3: A plan drawing of Edirne, II. Bayezid Hospital, with analysis of functional spaces according to various reliability degrees shown in different colours [9].

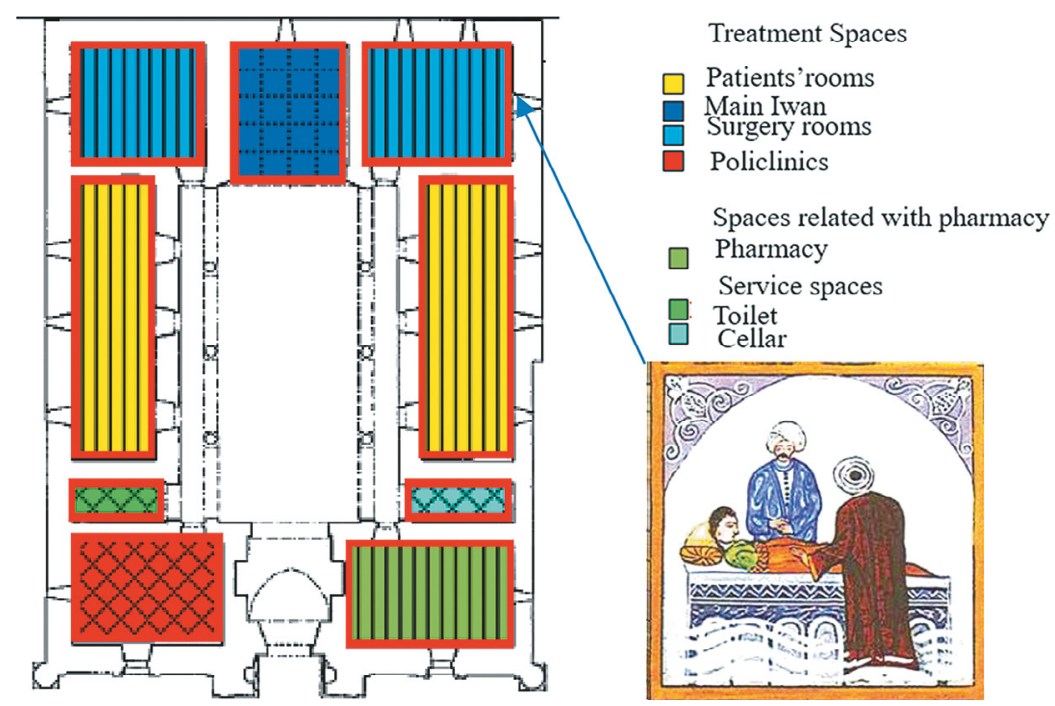

Figure 4: A plan drawing of Amasya, Anber Bin Abdullah Hospital, with analysis of functional spaces shown in different colours (left) and a scene from surgery room depicting the treatment of a patient (right) (drawn by Inci Özen) $[9,16]$. 

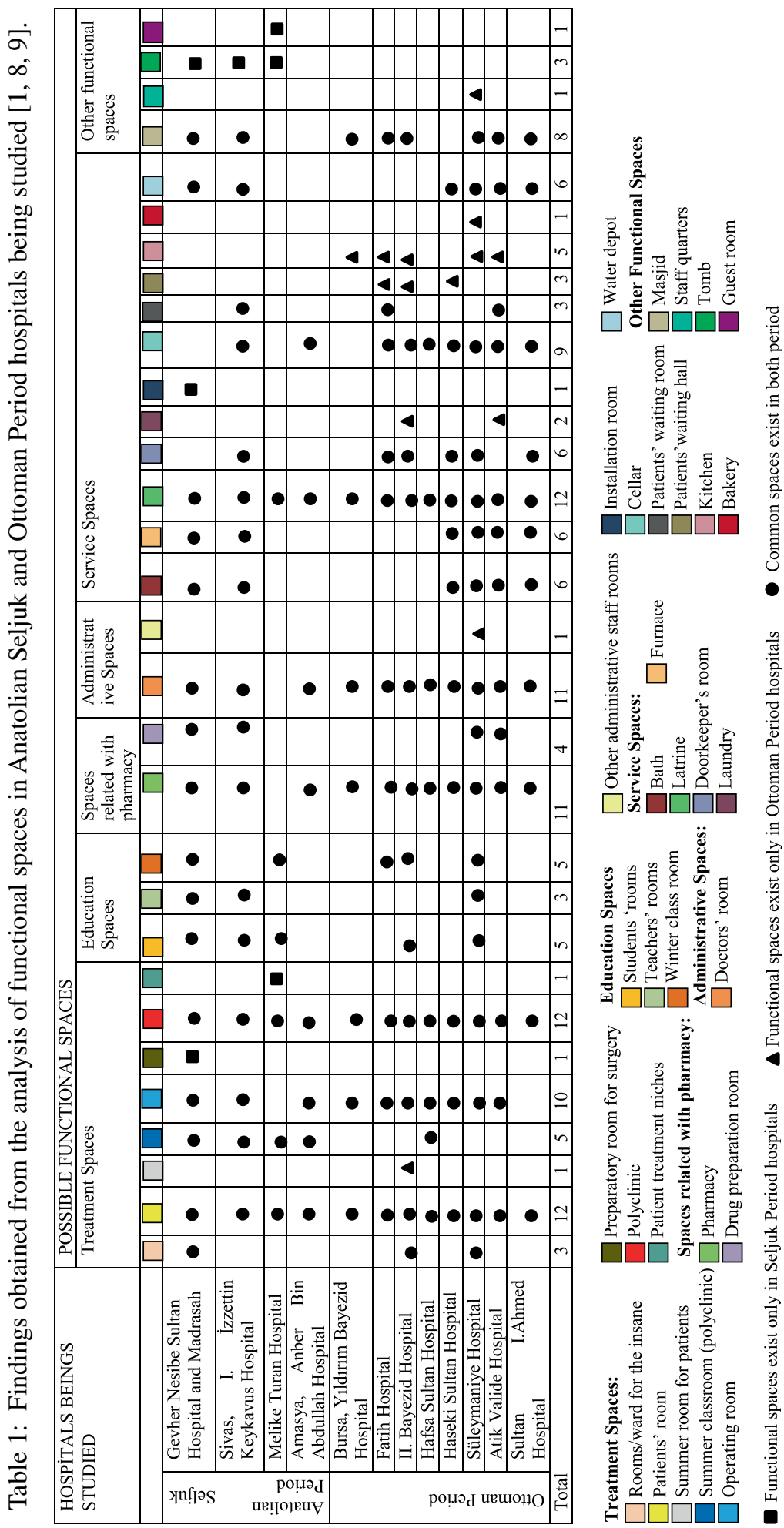
possible bath and pharmacy of Istanbul, Haseki Sultan Hospital, latrines, pharmacy and patients' rooms of Bursa, Yıldırım Bayezid Hospital, laundry and patients' rooms of Istanbul, Atik Valide Hospital, and masjid, bakery, kitchen and bath sections of Istanbul, Süleymaniye Hospital, could have been detected (Fig. 2). Similarly, bath sections, wall fountains, pools and wells inside the hospitals, fireplaces of patients' rooms and their chimney extensions are some other indicators of relationship between functional spaces and functional systems [1, 8].

During the determination of functional spaces and their possible locations in each hospital, the data have been compiled by using primary and secondary sources in accordance with their reliability degrees, classifications of which have been shown below (Figs 2-4) [1, 9];

The existence and location in the hospital is known exactly from the primary sources

DI The existence is known from the primary sources but the exact location is unknown The existence and/or location is known from the secondary sources:

Scholars agree on both the existence and location

Scholars have different interpretations in terms of existence and/or location

Scholars have no interpretations both in terms of existence and location

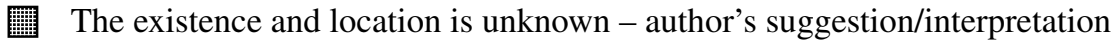

There are some notable changes in functional space design of hospitals during the transition period from the Anatolian Seljuk to the Ottoman era. Findings obtained from the analysis of functional spaces in these period hospitals have been outlined in Table 1. These changes can be classified as follows $[1,8,9]$ :

- Increase in the number of functional spaces from Seljuk to Ottoman period; designing different spaces almost for all different functions. Bakery, summer and winter rooms for patients, patients' waiting rooms/halls, kitchen and staff quarters are examples for new functional space developments for different needs in Ottoman hospitals (Table 1). Laundry space of Edirne, II. Bayezid Hospital and Istanbul, Atik Valide Sultan Hospital is the other example for the increase in the number of functional spaces in Ottoman period [1].

- Disappearance of some of the functional spaces in Ottoman period; planning different functional spaces in the mosque complex instead of as part of the hospital itself. For instance, tombs of Seljuk period hospitals such as Sivas, I. Izzeddin Keykavus Hospital, Kayseri, Gevher Nesibe Hospital and Medicine Madrasah and Divriği, Melike Turan Hospital have never been seen in Ottoman period hospitals. Surgery preparatory room, guest room, patient treatment niche, installation room, main iwan and side iwans are the other functional spaces observed only in Seljuk period and never in Ottoman era.

- Change in the function of some functional spaces during the transition period. For instance, the niches used for the treatment of patients in Divriği, Melike Turan Hospital of Seljuk period, turned into summer room for patients in Edirne, II. Bayezid Hospital of Ottoman period. Similarly, patients' waiting rooms/halls of Seljuk period, mostly designed as a closed space, were arranged as semi-open spaces in front of policlinics in Ottoman period, examples of which can be seen in Istanbul, Fatih and Haseki Sultan Hospitals and in Edirne, II. Bayezid Hospital [1].

- Separation of spaces used for two different functions. For instance, in Seljuk period, masjids were often designed at the same space with the tombs such as in Kayseri, Gevher Nesibe Hospital and Medicine Madrasah. But in Ottoman period, masjids were either de- 
signed as a different space in hospital itself as in Süleymaniye and Atik Valide Hospitals or as a totally separate space located in the mosque complex.

- Change in locations of different functional spaces inside the hospitals. As an instance, although the rooms on the left and right sides of the entrance were often used as policlinics in Seljuk period hospitals, in Ottoman period, policlinic rooms were often located around a separate courtyard with waiting halls in front, as in Edirne II. Bayezid Hospital, Haseki Sultan Hospital and Fatih Hospital.

There are also some similarities in functional space design of hospitals built in Anatolian Seljuk to the Ottoman periods. These similarities can be classified as follows $[1,8,9]$ :

- Separation of rooms/wards for the insane from the patient treatment rooms in both periods. Either a separate corridor or courtyard is allocated for the insane in historic hospitals of Anatolia. For instance, in Kayseri Gevher Nesibe Sultan Hospital and Medicine Madrasah, ward for the insane was located along a separate hall, and in the Süleymaniye Hospital it was located on the basement floor. On the other hand, in the Edirne II. Bayezid Hospital, a separate courtyard is allocated for the mental patients' rooms [1, 8] (Figs 2 and 3).

- Location of patients rooms/wards generally around a courtyard, behind a colonnaded portico in both periods. For instance, this arrangement is seen in Amasya, Anber Bin Abdullah Hospital, Sivas, I. Izzeddin Keykavus Hospital, Kayseri, Gevher Nesibe Hospital and Medicine Madrasah, Bursa, Yıldırım Bayezid Hospital, Istanbul, Fatih, Süleymaniye, Atik Valide and Sultan I. Ahmed Hospitals (Fig. 4).

- Designing functional spaces by taking into account the hierarchy between the staff and the space allocated for them. For instance, in Istanbul, Süleymaniye Hospital and in Edirne, II. Bayezid Hospital, treatment spaces and service spaces have been located along different separate courtyards. Similarly, in Seljuk hospitals as seen in the Kayseri Gevher Nesibe Sultan Hospital and the Medicine Madrasah and in the Divriği Melike Turan Hospital, such a hierarchical design is observable between treatment and education spaces (Figs 2 and 3).

- Designing patients' rooms as separate spaces as in Kayseri Gevheri Nesibe Hospital and Bursa, Yıldırım Bayezid Hospital or as ward arrangements as in Amasya Anber Bin Abdullah Hospital. In Istanbul, Süleymaniye Hospital, there is ward arrangement for the insane and separate rooms for the other patients (Figs 2 and 4).

\section{A RESEARCH ON ORIGINAL FURNISHING DESIGN IN CASE STUDY HOSPITALS}

Unstructured elements of a building, such as mechanical and electrical fixtures, and builtin and moving furniture, are the ones located inside a building by the users or owners of the building [17]. Literature from many disciplines enriches the history and architecture of historic hospitals, but it provides only limited information related to the documentation and inventory of historic furnishings, fixtures and equipment of these buildings. Primary sources such as miniatures, waqf deeds, traveller's accounts, accounting records and gravures give us more insight into the original furnishing of spaces in historic hospitals of Anatolia. By examining the waqf deeds and old accounting records of the waqf buildings including hospitals, it is clear that most of the revenues of the waqf were spent for construction, maintenance, 
repair, cleaning of the building and for the wages of the staff [18]. Nonetheless, it is not always possible to find details related to furnishing expenses such as carpets and rugs in all waqf deeds, the reasonable explanation of which might be that they were relatively low cost and mostly met through donations or gifts of charitable bodies [1, 18]. Even in some cases, furnishing and other essential goods such as carpets, rugs, mats, oil lamps, oil, sacks, carpet bags, and embroidery canvases were laid down as a condition to be bought and renewed via the revenues of the waqf, but they were never registered among its expenses [18].

If we look at the few examples, in Nurbanu Valide Sultan waqf deed dated 1582, it is written that in Atik Valide Hospital, two laundrymen were to be allocated for cleaning the clothes, mattresses and duvets of the patients, and three dirham were to be paid to them for this duty and two dirham were to be purchased for the mats and candles of the masjid, madrasah and guest room of the mosque complex [19]. Similarly, in Bayezid- Han-1 Sani (Veli) waqf deed dated 1487, it is written that in Edirne, II. Bayezid Hospital three dirham were to be purchased for the incense, buckets and oil of the oil lamps and in Sultan Süleyman Han bin Selim Han waqf deed it is explained that in Süleymaniye Hospital, two laundrymen were to be allocated for cleaning the clothes and beds of the patients [19]. In the same way, from the Mehmed Han-1 Sani bin Murad Han waqf deed dated 1471, it is understood that in Istanbul, Fatih Hospital, two people were to deal with preparing the beds and cleaning the cloths of the patients, and in total a 100 dirham were to be purchased for all kinds of furnishings, devices and equipment necessary for the patients and the hospital including duvets, beds, cloths and blankets [19].

In accounting records dated 1489-1490 belonging to the imaret, madrasah and hospital in Edirne, and Istanbul, Fatih Mosque Complex, it was written that mat, carpet, rug, sack and carpet bag were bought from the revenues of the waqfs [18]. In Edirne II. Beyazid Hospital and Madrasah similarly, registered movable fixtures were counted as follows $[1,20]$ :

- In hospital section, special chains to tie the insane, special devices for the use of ophthalmologist and surgeons, 30 mattresses, 30 duvets, 64 pillows, eight pots, two bowls, two big pots, two water jugs, 16 buckets, two trays, six cups and 15 small flasks for sprinkling rose water [20],

- In madrasah section, two carpets, 46-48 books kept in a coffer, firewood and oil lamp. Daily furnishings and household goods such as mat, oil lamp, pillow, firewood and duvet might have been provided by the students, since in the waqf deed it was only written that one silver coin had to be purchased for the oil and oil lamp without mentioning other furnishings [20].

1847 Regulations of Gureba Hospital, a part of Bezmialem Valide Sultan waqf, also give detailed information about the furnishing organization in hospitals such that beds and duvets of the patients were to be adjusted and selected pursuant to the necessities of different seasons, and cleaning and arrangement of the beds were to be conducted according to the suggestions of hospital manager, physician and chief surgeon [19]. Similarly, a waqf accounting register dated 1578 belonging to Bursa, Yıldırım Hospital, gave information about the expenses of death incidences. It is understood from this document that 1078 silver coins were spent for enshrouding 29 death incidences in the hospital in that year, and in a repair register of the hospital dated 1669, it was written that chief physician's room together with 24 rooms were repaired and a cellar and two cabinets were added to the hospital during this repair work [21]. 
Travellers' accounts are also important sources to get information on inpatients' clothes and hospital furnishings. For instance, by means of the accounts of 17th-century Turkish traveller Evliya Çelebi, it is understood that in Fatih Hospital, inpatients 'had richly embroidered silk cloths and silk nightwear with silver thread' [22]. Similarly, for the Edirne II. Beyazit Hospital, Evliya Çelebi quoted the following [23];

In some of the rooms, in winter days, the patients, leaning to silk pillows and sitting on the mattresses and duvets embroidered with silver thread, wailed towards the fire lightening the room. And in some of the rooms in spring days, season of insanity, the insane were fastened to golden or silver chains in their rooms.

In addition to the accounts of Evliya Çelebi, thanks to the research conducted by Omer Lutfi Barkan on an accounting register dated 1490 belonging to Edirne, II. Bayezid Hospital, it was possible to get information on the clothes of the staff working in the hospital. In this register, shirts for surgeons and sherbet makers, cotton for patients and surgeons, apron for servants, 14 nightshirts, 29 pearl, 175 silver coins for cleaning the patients in the bath and 203 silver coins for the burial procedures of the death were recorded among the expense items of the hospital [24, 25].

In addition to hospitals, there were also 'doctor's stores' which were special consulting rooms, also functioned as pharmacies and could only be opened with the permission of a chief physician [2, 21] (Figs 5 and 6). Different from the hospitals, in these 'doctor's stores',

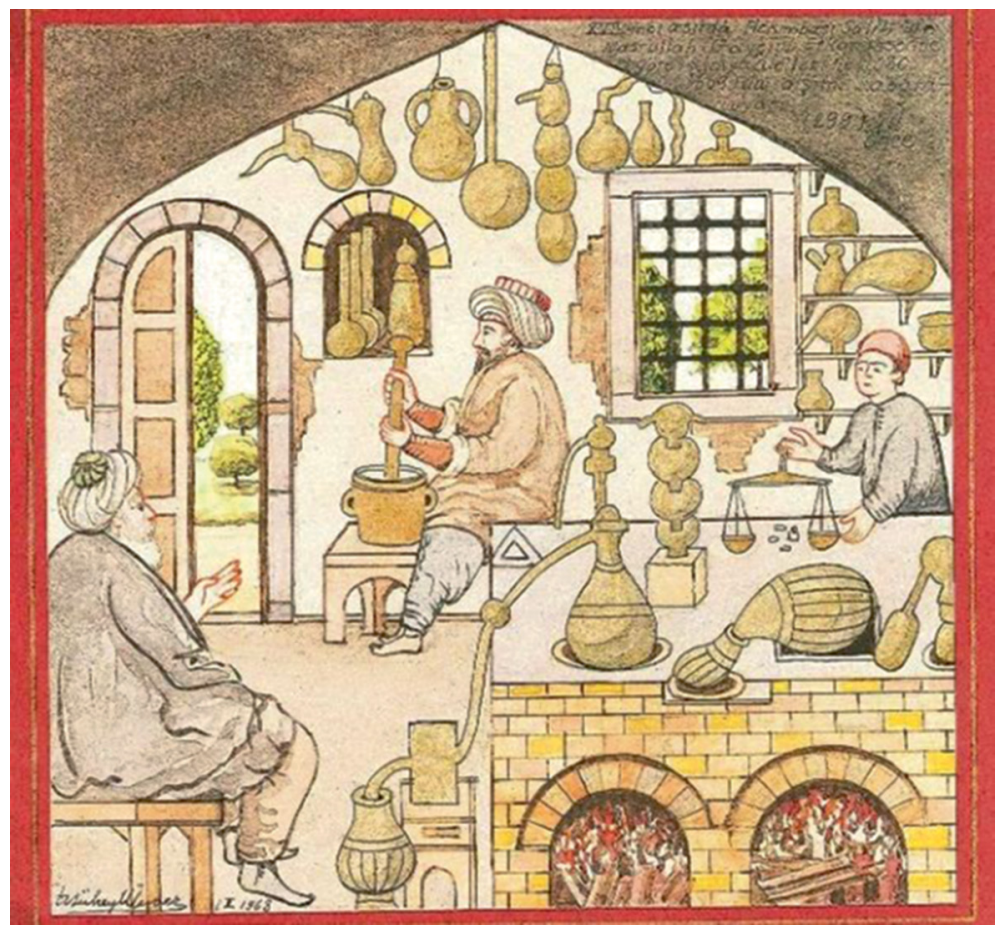

Figure 5: Illustration of a chief physician Salih b. Nasrullah during preparation of medicine (Archives of Süheyl Ünver and G. Mesera, drawn by Süheyl Ünver in 1968) [26]. 

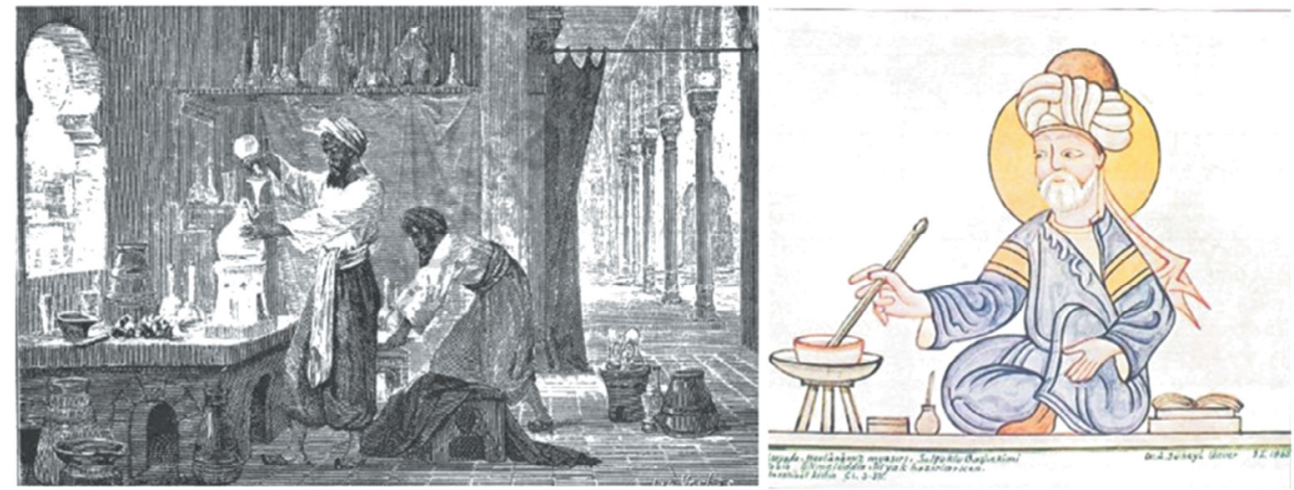

Figure 6: Muhammed İbn Zekeriya el-Razi, while working in his laboratory (left) and depiction of the chief physician Ekmelüddin from Seljuk period preparing medicine (right) (Menakıbul Arifin, v.1, p. 371, redrawn by Suheyl Unver in 1968) [7, 27].

the patients had to pay a certain amount of fee for their treatment [21]. Understanding the furnishing design of these doctor's stores might also have been important in order to understand better the furnishing design in the hospitals.

Miniatures, gravures, illustrations and exhibitions depicting hospitals also show different treatment scenes and type of beds that the patients lied on (Fig. 8). It is understood that patients inside the hospitals slept either on mattresses laid directly on the ground or on a kind of a four-legged bedstead with a duvet and pillow inside, and sat on wooden seats when they were in the courtyards (Figs 7 and 8) [1]. Patients' laundry, bedding and duvets were cleaned
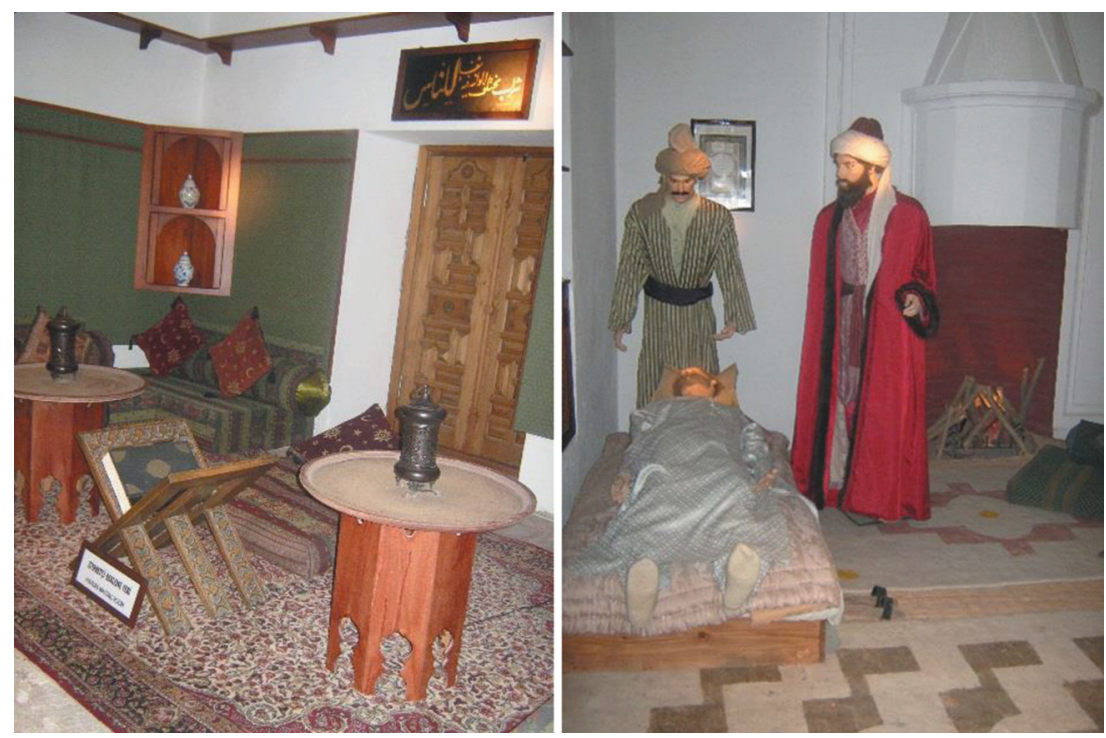

Figure 7: Depictions of visitors' waiting hall (left) and room of an epileptic patient treated by a doctor and a nurse (right) in Edirne II. Bayezid Hospital, which is used as a museum today (photo: author's archives, 2011). 

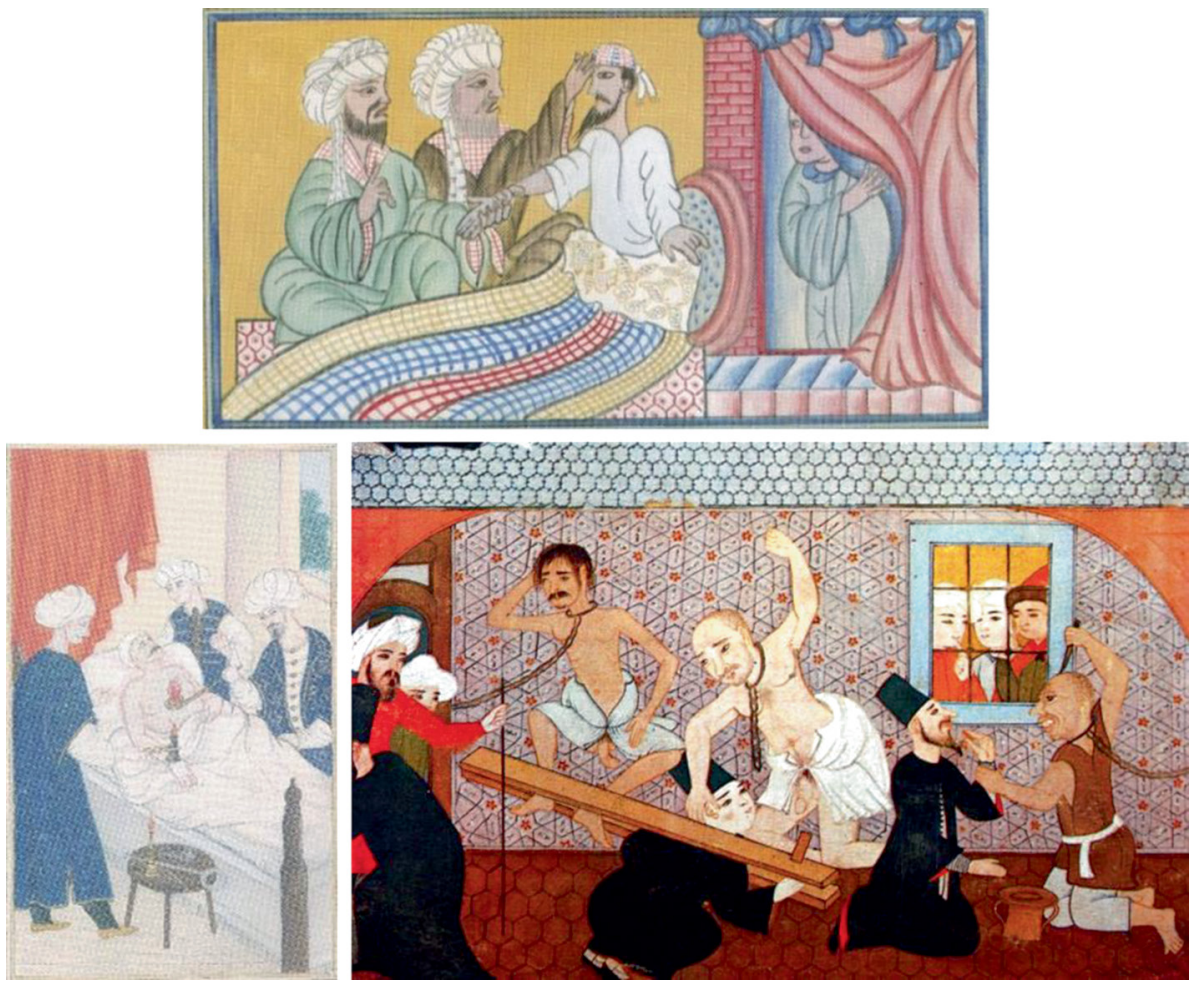

Figure 8: An illustration of a visit and consultation to Sultan Giyas al-Din Muhammed B. Mahmud lying at his bed (top), a patient in a hospital treated with burning a balsam (bottom left) (painted by Ülker Erke), and a miniature in an Ottoman Hospital showing treatment of insane patients in a special room (bottom right) (Album of Sultan I. Ahmet, Topkapı Palace Museum, Number: 3408) [5, 24].

by laundrymen called as 'jamayush' [2]. By analysing miniatures, it is also possible to get some additional information on the transfer of patients to the hospitals. The patients were carried to the hospital with a wheeled cart, a wooden stretcher or on the shoulders of another person (Fig. 9) [1, 5].

Healing bowls, censers and healing shirts are also worth mentioning under the heading of this research. Healing bowls, around which were inscribed with Qur' anic verses, were used to give water to the sick, and censers were a kind of a case in which medicinal herb was burnt in order to cure the sick (Fig. 10). Healing shirts were similarly believed to protect people from the illnesses and all kinds of evils and at the same time to cure the patients [28]. Those healing shirts were mostly made of thin, cotton fabric and were quite popular among the Sultans, people in the dynasty, dervishes, and the sick, especially between 15 th and early 20 th centuries [28].

\section{CONCLUSIONS}

This study has shown how primary and secondary sources such as gravures, miniatures, accounting registers, historic photographs, excavation reports and travellers' accounts of the hospitals, as well as in situ observations, can be used to locate original functional spaces and 

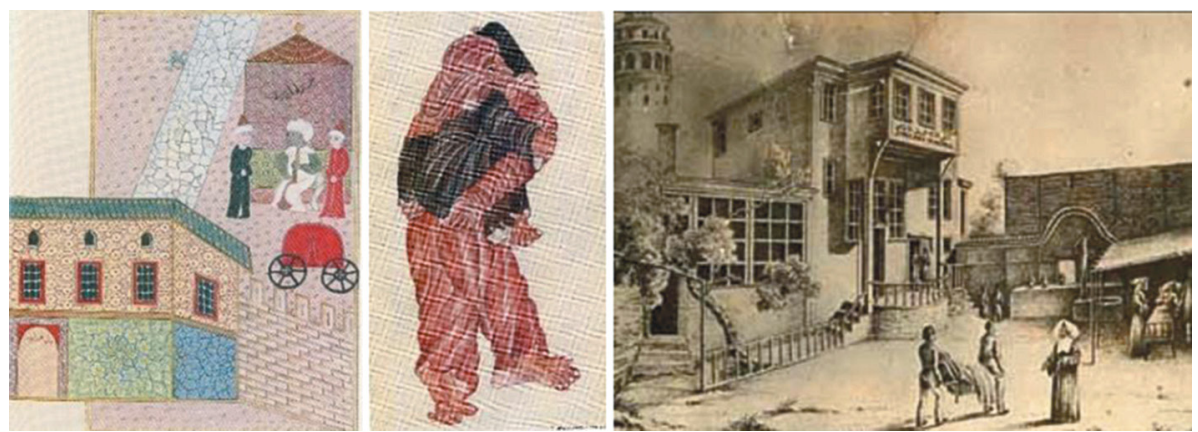

Figure 9: A miniature of patients' room with a wheeled patient cart in front of Enderun Hospital (left) (Hunername, Archives of Topkap Palace Library, Nr. 1523, painted by Ülker Erke), a paralyzed patient transferred on the shoulders of another person (centre) (Topkapı Museum Book Number H. 2153. Vr. 55a, painted by Suzan Çataloluk Lüteci) and Beyoglu Municipality Hospital, patient carried with a wooden stretcher (right) (Archives of Nuran Ylldırım) [3, 5].
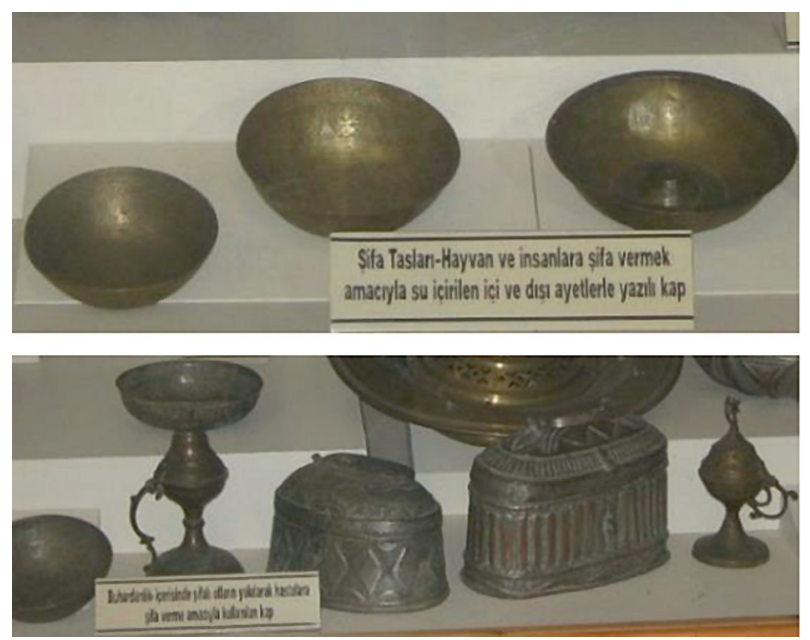

Figure 10: Healing bowls (top) and censers (below) exhibited in Kars Museum (photo: author's archives, 2011).

their furnishings in historic hospitals. Thanks to these sources, it is understood that either moving or built-in furnishings, and fixtures and equipment in functional spaces of historic hospitals collectively reflect their regional features and developmental stage in their own period as well [1]. By examining rather a few historic hospitals in Anatolia that remain to us, it became possible to understand how wisely they were planned as ideal models of Ottoman architecture [8]. The research has proved that there are both differences and similarities between Seljuk and Ottoman period hospitals in terms of functional space developments, their hierarchy, locations and numbers. Increase in the number of functional spaces from Seljuk to Ottoman period, disappearance of some of the functional spaces in Ottoman period, 
change in the role of some functional spaces during the transition period, separation of spaces used for two different functions and change in locations of different functional spaces inside the hospitals can be counted among the notable changes observable between the two periods. Separation of rooms/wards for the insane from the patient treatment rooms, courtyard plan type and designing functional spaces taking into account the hierarchy between the staff and the space allocated for them have been the primary similarities of the two periods with regard to functional space arrangement of hospitals. Regarding the original furnishing design, an important component of collective memory revealing the conditions of its period, waqf deeds, accounting registers and travellers accounts were important sources referred during the research $[1,29]$. Carpets, rugs, carpet rugs, oil lamps, duvets, mattresses and pillows were among a few details related to furnishing expenses mentioned in those archival sources. Unfortunately, these expenses were hardly included in all waqf deeds, because possibly they were relatively low cost and mostly met through donations of charitable bodies. The study presented here can be evaluated as a beginning step on possible original functional spaces and furnishing designs in 13th- to 17th-century hospitals of Anatolia, but in future it will be fruitful to look at those of the 19th- and early 20th-century periods, using the same systematic approach. Thus, it might be possible to see developmental stage of planning of functional spaces and furnishings towards the modern hospitals and possible interactions, applicability and adjustment of past and present ones. Another area that might prove useful for future research is the study of how the ideas of medicine, nursing and technology that became more predominant in the early 20th century in shaping the essentials of functional spaces and designs of historic hospitals affected space planning in later periods.

\section{ACKNOWLEDGEMENT}

I am grateful to Prof. Dr. Zühal Özcan, my advisor of dissertation studies, this article being a part of it. In addition, Prof. Dr. M. Can Hersek and Prof. Dr. Z. Gediz Urak deserve special thanks for all their helpful advices and directions during my PhD studies.

\section{REFERENCES}

[1] Dişli, G., Functional spaces and furnishing designs in the historical Anatolian Seljuk and Ottoman hospitals. WIT Transactions on the Built Environment, Vol. 177, ed. G. Passerini, WIT Press: Southampton and Boston, pp. 209-220, 2018, ISBN 978-178466-251-6. DOI: 10.2495/IHA180181.

[2] Altıntaş, A., Medicine and darüşşifas in the Anatolian Seljuk and Ottoman Empires. The Sifahanes of Philanthropic Monuments of the Seljuk and Ottoman Eras, ed. A. Kılıç, Medicalpark: Istanbul, pp. 23-61, 2012, ISBN 978-9944-0104-1-2.

[3] Yıldırım, N., A History of Healthcare in Istanbul, Duzey Matbaacılık: Istanbul, pp. 38, 43-47, 152, 159, 217, 2010, ISBN 978-605-4123-15-5.

[4] Terzioğlu, A., Osmanlılarda Hastaneler, Eczacılık, Tababet ve Bunların Dünya Çapında Etkileri, T.C. Kültür Bakanlığı: İstanbul, pp. 5-7, 1999.

[5] Erke, Ü. \& Sarı, N. (eds), Turkish medical history through miniature pictures exhibition. 38th International Congress on History of Medicine, Nobel Matbaacilik: İstanbul, pp. 114, 151, 153, 157, 162-163, 2002, ISBN 975-420-256-5.

[6] Cantay, G., Anadolu Selçuklu ve Osmanlı Darüşşifaları, Atatürk Kültür Merkezi: Ankara, 1992, ISBN 975-160-508-3.

[7] Kılıç, A. (ed), The Şifahanes of Philanthropic Monuments of the Seljuk and Ottoman Eras, Medicalpark: Istanbul, pp. 36, 39, 2012, ISBN 978-9944-0104-1-2. 
[8] Dişli, G., Planning of functional spaces in Ottoman Period hospitals (darüşşifa) of Anatolia. Al-Masaq: Journal of the Medieval Mediterranean, 27(3), pp. 253-276, 2015. DOI: 10.1080/09503110.2015.1102502.

[9] Disli, G., Anadolu Selçuklu ve Osmanlı Darüsşifalarında İşlevsel Sistemlerin ve Koruma Ölçütlerinin Irdelenmesi, PhD Dissertation, Gazi University, Ankara, Turkey, (in Turkish), pp. 27-45, 145-187, 2014.

[10] Disli, G., Sustainability of historic building systems: Anatolian Seljuk and Ottoman hospitals. APT Bulletin: Journal of Preservation Technology, 45(4), pp. 45-51, 2014.

[11] Disli, G. \& Ozcan, Z., Waste and clean water systems in Anatolian Seljuk and Ottoman Period hospitals. International Journal of Academic Research, 6(3), pp. 169-177, 2014. DOI: $10.7813 / 2075-4124.2014 / 6-3 / A .23$.

[12] Dişli, G. \& Özcan, Z., An evaluation of heating technology in Anatolian Seljuk Period hospitals (darüşsifa). Metu Journal of Faculty of Architecture, 33(2), pp. 183-200, 2016. DOI: 10.4305/METU.JFA.2016.2.8.

[13] Disli, G., Analysis of ancient ventilation and illumination practices in Anatolian Seljuk and Ottoman hospitals and suggestions for their conservation measures. International Journal of Heritage Architecture, 2(1), pp. 174-185, 2018. DOI: 10.2495/HA-V2N1-174-185.

[14] Özcan, Z. \& Dişli, G., Refrigeration technology in Anatolian Seljuk and Ottoman Period hospitals. Gazi University Journal of Science, 27(3), pp. 1015-1021, 2014.

[15] Dişli, G. \& Özcan, Z., Roof drainage systems applied in Anatolian Seljuk and Ottoman Period hospitals. Yapı Üretimi, Kullanımı ve Koruma Süreçleri, 2nd National Building Congress and Exhibition, eds. T. Arslan-Konak \& A. Tavukçuoğlu, TMMOB Mimarlar Odası Ankara Şubesi: Ankara, pp. 337-350, 2015, ISBN: 978-605-01-0735-7.

[16] Sarı, N., Mesara, G. \& Kurt, Ü.E. (eds), Amasya Selçuklu ve Osmanlı Mimarisi ve Bezemeleri, Ord. Prof. Dr. A. Süheyl Ünver Nakışhanesi Yorumuyla, Amasya Valiliği: İstanbul, p. 31, 2007, ISBN 978-975-585-808-1.

[17] İpek, C., Deprem etkisi altindaki yapisal olmayan sistemlerin incelenmesi. Proceedings of the Kocaeli 2015 5th International Earthquake Symposium, pp. 187-199, 2015.

[18] Deniz, B., Bir vakıf eser olarak cami, mescit, zaviye, şifahane gibi dini ve sosyal yapılarda bulunan halı kilim ve düz dokuma yaygılar ve bunların günümüzdeki durumu. Vakıflar Dergisi, 23, pp. 283-296, 1994.

[19] Archives of Directorate General of Foundations.

[20] Müderrisoğlu, F., Edirne II. Bayezid Külliyesi. Vakıflar Dergisi, 22, pp. 151-198, 1991.

[21] Çetin, O., İlk Osmanlı Hastanesi, Bursa Yıldırım Darüşşifası (Bursa Mahkeme Sicillerine Göre), Göz Nurunu Koruma Vakfı Yayınları: İstanbul, pp. 40, 65, 70, 116 118, 138, 2006.

[22] Kahraman, S.A. \& Dağlı, Y. (eds), Günümüz Türkçesiyle Evliya Çelebi Seyahatnamesi: Istanbul Vol. I/I, Yap1 Kredi Yayınları: Istanbul, pp. 276-277, 2003, ISBN 975-080563-1.

[23] Kahraman, S.A. \& Dağl1, Y. (eds), Günümüz Türkçesiyle Evliya Çelebi Seyahatnamesi: Konya, Kayseri, Antakya, Şam, Urfa, Maraş, Sivas, Gazze, Sofya, Edirne, Vol. III/II, Yap1 Kredi Yayınları: Istanbul, pp. 607-608, 2006, ISBN 975-08-1102-X.

[24] Şengül, E., Kültür Tarihi İçinde Müzikle Tedavi ve Edirne Sultan II. Bayezid Darüşşifası, Master's Thesis, Trakya University, Edirne, Turkey, pp. 116, 170, 2008.

[25] Barkan, Ö.L., Edirne ve civarındaki bazı imâret tesislerinin yıllık muhasebe bilânçoları. Belgeler, 1(1-2), 2nd ed., Türk Tarih Kurumu Basımevi: Ankara, pp. 235-377, 1993. 
[26] Bilgin, A., The herbs used to make medicine in Ottoman Period. Health in the Ottomans 1, 2 vols., eds. C. Yılmaz \& N. Yılmaz, Biofarma Ilaç Sanayi ve Ticaret A.S.: Istanbul, p. 251, 2006, ISBN 975-00993-1.

[27] Kahya, E. \& Erdemir, A.D., Bilimin Işı̆̆ında Osmanlıdan Cumhuriyete Tip ve Sağlık Kurumları, Türkiye Diyanet Vakfi Yayınları: Ankara, p. 443, 2000, ISBN: 975-389-359-0.

[28] Tezcan, H., Topkapı Sarayı Müzesi'nde bulunan sultanlara ait şifalı gömlekler. Proceedings of the 38th International Congress on the History of Medicine, eds. N. Sar1, A.H. Bayat, Y. Ülman \& M. Işın, Vol. II, Türk Tarih Kurumu Yayınları: Ankara, pp. 915-923, 2005, ISBN: 975-16-1825-8.

[29] Ultav, Z.T., Hasırc1, D., Atmaca, H. \& Borvalı, S., Türk modern mobilyasinin peşinde, Selçuk-Teknik Dergisi, Special Issue-1 (UMK-2015), pp. 480-497, 2015. 